\title{
Zpráva z konference Translation and Interpreting Forum Olomouc 2019: Teaching Translation vs. Training Translators
}

Ve dnech 15. a 16. listopadu 2019 se v prostorách Filozofické fakulty Univerzity Palackého uskutečnil pátý ročník mezinárodní konference Translation and Interpreting Forum Olomouc. Jak napovídá podtitul letošního ročníku Teaching Translation vs. Training Translators, konference se věnovala zejména otázkám souvisejícím s výukou překladu a tlumočnictví, tedy např́klad roli teorie a praxe při př́pravě budoucích překladatelů a tlumočníků, využitelnosti moderních technologií ve výuce nebo schopnostem a dovednostem, jaké by si měli začínající překladatelé a tlumočníci osvojit před vstupem na trh. Program obou konferenčních dnů nabídl celou řadu zajímavých přednášek věnovaných dalším aktuálním tématům, jakými jsou literární překlad, překlad do nemateřského jazyka nebo třeba využití překladu při výuce cizích jazyků. Přestože oba hlavní hosté, kteř́ svými př́spěvky zahájili páteční a sobotní program, jsou překladatelé a vyučují překlad, na konferenci zazněla i výhradně tlumočnická témata.

První den konference zahájil Luc van Doorslaer, který působí na univerzitách v belgické Lovani a v estonském Tartu. V úvodu svého př́spěvku hovořil o teorii a praxi a o jejich úloze ve výuce překladu. Podělil se o svou zkušenost se začínajícími studenty, kteří na teorii mnohdy nahližejí jako na nutné zlo, a proto by si přáli, aby byly hodiny zaměřené pouze na praxi. Ti samí studenti však podle Luca van Doorslaera během svého studia mnohdy změní názor, uvědomí si, nakolik jim může být teorie užitečná, a začnou se o ni zajímat $\mathrm{z}$ vlastní iniciativy. $\mathrm{V}$ další části přednášky se řečník zamyslel nad tím, proč jsou překladatelé a tlumočníci vnímáni jako neviditelné a neutrální postavy. $\mathrm{V}$ obou profesích je přitom téměř nemožné být neviditelný. Jak překladatelé, tak tlumočníci jsou aktivními hráči, kteří mají možnost volby a komunikační situaci nutně ovlivňují. Podle Luca van Doorslaera se proto nabízí otázka, proč si překladatelé a tlumočníci za svého patrona vybrali svatého Jeronýma, proč si nevybrali spíše Hermése. Ten byl koneckonců božím poslem a pohyboval se mezi dvěma světy: světem smrtelníků a světem bohů. Pokud by byl Hermés patronem překladatelů a tlumočníků, nejenže by pomohl vytvořit na obě profese zcela rozdílný pohled, samotní překladatelé a tlumočníci by svou roli vnímali odlišně.

Po úvodním př́spěvku následoval diskusní panel moderovaný Ondřejem Klabalem z Katedry anglistiky a amerikanistiky (UPOL). Kromě Luca van Doorslaera se panelu zúčastnilo dalších pět osobností včetně druhého hlavního hosta konference, překladatelky Chris Durbanové. Do diskuse byla dále přizvána tlumočnice Jana Rejšková a překladatel David Mraček, který působí na Ústavu translatologie FF UK. V neposlední řadě se diskuse zúčastnili Martin Svoboda, překladatel a redaktor z nakladatelství Argo, a Martin Štulík, překladatel a zakladatel společnosti Orange Tree.

Diskusní panel se dotkl celé řady aktuálních témat, přičemž nejzajímavější debata se rozvinula kolem překladu do nemateřského jazyka. Jednotliví řečníci totiž zaujímali poměrně odlišná stanoviska, což bylo dáno také tím, že mezi nimi byli nejen překladatelé, ale i tlumočníci, případně vyučující překladu i tlumočení. Chris Durbanová, která překládá $\mathrm{z}$ francouzštiny do angličtiny a ve své praxi se věnuje zejména obchodním a finančním textům, odmítá, aby překladatelé pracovali do svého nemateřského jazyka, 
pokud nemají k dispozici profesionálního korektora. Zdůraznila ovšem, že není možné takto kategoricky odmítat tlumočení do nemateřského jazyka. Tím navázala na slova Jany Rejškové, která toto téma vztáhla k domácímu trhu, jenž po tlumočnících vyžaduje, aby do svého nemateřského jazyka běžně tlumočili a překládali. Odlišná situace se na zdejším trhu týká zejména literárních př̀kladatelů, kteří pracují převážně do svého mateřského jazyka, jak během diskuse poznamenal Martin Svoboda. Do debaty se zapojil také David Mraček, který zastává ten názor, že překlad do nemateřského jazyka může být užitečným nástrojem při přípravě budoucích překladatelů. Zároveň je podle něj nutné umět studenty správně směrovat tak, aby dokázali odhadnout své schopnosti.

Odpolední program prvního dne konference zahrnoval šest sekcí, během každé bylo představeno hned několik prríspěvků s obdobnou tematikou. Jedna ze sekcí byla například věnována simultánnímu tlumočení a zaměřila se zejména na měnící se pracovní podmínky tlumočníků a na kvalitu tlumočení, která s nimi jde nutně ruku v ruce. O technologiích, které čím dál tím častěji nahrazují tlumočnické kabiny, hovořil ve svém příspěvku Tomasz Korybski z Varšavské univerzity. Hovořil o bezdrátových systémech, které běžně využívají průvodci a které se v současnosti využívají také pro tlumočení. Přestože tyto systémy vedou ke zhoršení kvality tlumočení, pro mnoho klientů, kteří si objednávají tlumočnické služby, je důležitější, že díky bezdrátovým systémům šetří náklady. Je nezbytné, aby se na využití těchto technologií zaměřil tlumočnický výzkum, a to zejména ve spojení s výukou, kvalitou a kognitivní zátěží, jaké je tlumočník při využívání těchto zařízení vystaven. Do následné diskuse se zapojili profesionální tlumočníci z publika, kteří se podělili o své zkušenosti s moderními technologiemi. Jedna diskutující například hovořila o tom, že ji její klienti čím dál častěji žádají, aby tlumočila na dálku, a to za použití chytrého mobilního telefonu.

Další z odpoledních sekcí se zabývala výukou překladu a jeho hodnocením. Také zde se hovořilo o moderních technologiích, například o platformách, které mohou studenti využívat k tomu, aby si osvojili nově nabyté znalosti. Jiří Rambousek z Masarykovy univerzity představil různé programy, které mohou posloužit jak při výuce překladu do nemateřského jazyka a výuce cizího jazyka obecně, tak při procvičování mateřského jazyka, a to zvláště při osvojování čtenářských dovedností. Padl zde totiž názor, že současní studenti nemají tak dobré znalosti svého mateřského jazyka, a to zejména v oblasti čtenářských schopností, jelikož často neznají klasická díla české literatury.

Druhý den konference zahájila Chris Durbanová se svým př́íspěvkem o překladatelském trhu, cenotvorbě a moderních technologiích. Úvodem vyjádřila své stanovisko $\mathrm{k}$ názoru, že překladatelé budou v blízké době nahrazeni strojovým překladem a že nebudou překládat, ale pouze posteditovat. Podle Chris Durbanové zastávají takový názor ti, kteří neznají prémiový trh, o němž hovořila Chris Durbanová nejen ve své sobotní přednášce, ale i během pátečního diskusního panelu. Na konkrétních překladech $\mathrm{z}$ francouzštiny do angličtiny pak ukázala nedostatky strojového překladu a překladu vyhotoveného překladatelem, který text přeložil za př́liš nízkou sazbu. Pokud má být překlad kvalitní, nemůže být vyhotoven za minimální cenu. Cenu by podle Chris Durbanové neměl určovat jen klient, ale také sám př̀kladatel. Ten by měl spolupracovat s takovými klienty, pro které není cena stěžejním kritériem a kteří jsou ochotní kvalitní př̌eklad adekvátně odměnit. 
Také sobotní program konference nabídl několik úzce zaměřených sekcí. Jednou z nich byla sekce věnovaná výuce tlumočení. Zde byla mimo jiné představena Mezinárodní jarní škola tlumočení, která se konala v dubnu 2019 na Ústavu translatologie Filozofické fakulty Univerzity Karlovy. O Mezinárodní jarní škole tlumočení, které se zúčastnilo celkem padesát dva studentů z dvanácti univerzit, hovořila na TIFO 2019 Ivana Čeňková. Zajímavým tématem se zabývala také další ze sobotních sekcí, během níž se diskutovalo o roli překladu při výuce cizích jazyků. Nejen jednotliví přednášející, ale i další diskutující, kteří se do debaty zapojili, zdůraznili užitečnost překladu při výuce cizích jazyků a odmítli, aby bylo učitelům cizích jazyků zakazováno do výuky zapojovat mateřský jazyk jejich studentů. Přednášející a diskutující se shodli na tom, že taková praxe může být někdy dokonce kontraproduktivní a studentům s osvojením cizího jazyka nepomáhá.

Ústav translatologie na TIFO 2019 zastupovali výše zmínění vyučující: Ivana Čeňková, David Mraček a Jana Reǰ̌ková a dále Tomáš Duběda, který na konferenci hovořil o překladu právních textů do nemateřského jazyka, a Věra Kloudová a Petra Mračková Vavroušová, které zde představily př̀klad románu Berthy von Suttner Die Waffen nieder, na jehož vzniku se podíleli studenti z Ústavu translatologie.

Účastníci konference se mohli zapojit do bohatého doprovodného programu, který pro ně připravili organizátoři konference $\mathrm{z}$ Katedry anglistiky a amerikanistiky (UPOL). $Z$ doprovodného programu stojí za zvláštní zmínku koncert, který se konal v pátek večer po skončení prvního dne konference v nádherných prostorách kaple Božího těla.

PhDr. Zuzana Balounová

Ústav translatologie, Filozofická fakulta, Univerzita Karlova

Zuzana.Balounova@seznam.cz

https://doi.org/10.14712/24646830.2020.16 